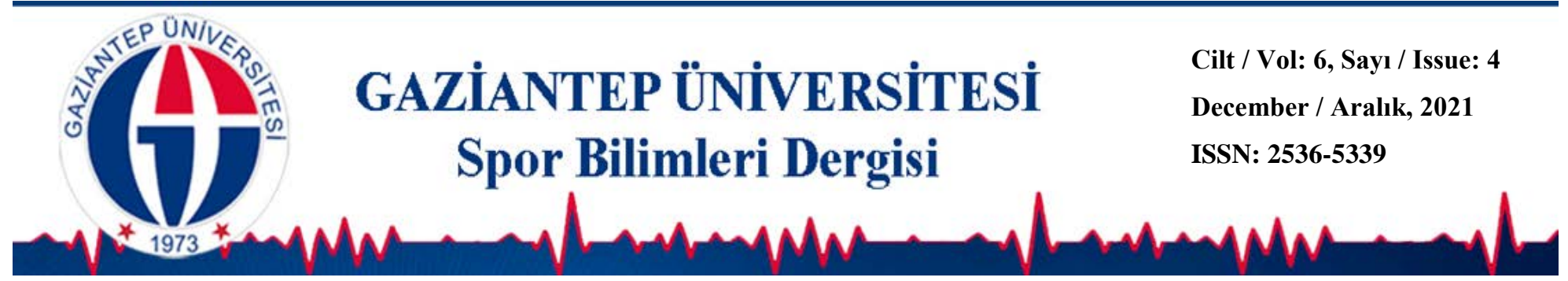

\title{
Üniversite Personelinin Sporda Güdülenme Düzeylerinin Araştırılması: Recep Tayyip Erdoğan Üniversitesi Örneği
}

\author{
Nihal AKOĞUZ YAZICI ${ }^{1 *}$ \\ Esma MAÇÇA ${ }^{1}$ \\ ${ }^{1}$ Recep Tayyip Erdoğan Üniversitesi, Beden Eğitimi ve Spor Yüksekokulu, RİZE
}

do. DOI: 10.31680/gaunjss.952402

Orijinal Makale / Original Article

Geliş Tarihi / Received: 15.06.2021～Kabul Tarihi / Accepted: 11.11.2021
Yayın Tarihi / Published: 24.12.2021

Öz

Bu araştırmada; Recep Tayyip Erdoğan Üniversitesi personelinin sporda güdülenme düzeylerinin farklı değişkenlere göre araştıııması amaçlanmıştır. Çalışmanın evreni; Recep Tayyip Erdoğan Üniversitesinde görev yapmakta olan yaklaşık 1900 akademik ve idari personelden, örneklemi ise 273 akademik ve idari personelden meydana gelmektedir. Veri toplama kısmında ise Kişisel bilgi formu ile Pelletier ve arkadaşları (2013) tarafından geliştirilen, Sporda Güdülenme Ölçeği II uygulanmışı̆r. Ölçek 6 alt boyut ve her alt boyutta 3'er madde olmak üzere toplam 18 maddeden ve 7’li likert tipi sorulardan oluşmuştur. Ölçeğin orijinal adı Sport Motivation Scale II dir; Bu çalışmada ölçek SGÖ II şeklinde ifade edilecektir. Ölçeğin Türkçeye çevirisi, geçerlilik ve güvenilirlik çalışması ise Öcal ve Sakallı (2018) tarafından yapılmıştır. Bu çalışmada SGÖ II ve kişisel bilgi formu kullanılarak Recep Tayyip Erdoğan Üniversitesi personeline uygulanmıştır. İstatistik testlerde SPSS programı kullanıImıştır. Verilerin genel özelliklerini belirlemede tanımlayıcı istatisțik, frekans ve yüzde dağılımlar uygulanmıştır. İstatistik testler olaraknormallik testi (Kolmogorov Simirnov ve Saphiro Wilks) yapılmıştır. Normal dağılıma sahip veriler için $p<0,05$ anlamlılık düzeyinde ikili karşıllaştırmalarda bağımsız iki grup için t-testi yapıımış̧ır. Üç ve daha fazla grup karşılaştırmalarında ise tek yönlü Anova testi (Oneway) yapılmıştır Anlamlı bulunan farklılıklar için (post hoc) Tukeys' HSD yapılmıştır. Sonuç olarak; spor ile ilgilenen personelin yaşı ilerledikçe amaçları ve hedeflerinin değişmesi nedeniyle güdülenme düzeylerinin de bu durumdan etkilendiği, ayrıca, doktora düzeyindeki katııımcıların özümseme puanlarının sırasıyla üniversite, lise ve yüksek lisans eğitim düzeyindeki üniversite personelinden anlamlı şekilde daha yüksek olduğu söylenebilir.

Anahtar Kelimeler: Üniversite Personeli, Sporda Güdülenme, Spor.

\section{Investigation of the Motivation Levels of the University Staff in Sports: The Case of Recep Tayyip Erdogan University}

\begin{abstract}
In this study; It is aimed to investigate the motivation levels of the staff of Recep Tayyip Erdogan University in sports according to the differences. The universe of the study; Approximately 1900 academic and administrative staff working at Recep Tayyip Erdogan University, with a sample of 273 academic and administrative staff. In the data collection part, the personal information form and the Sports Motivation Scale II, used by Pelletier et al. (2013), were applied. The scale consists of 6 sub-dimensions and 3 items each, and a total of 18 items and 7-point Likerttype questions. The original name of the scale is Sport Motivation Scale II; This source scale is expressed as SSI II. Translation of the scale into Turkish and its validity and reliability study were carried out by Öcal and Sakallı (2018). On this page, SGÖ II and personal information form screen has been applied to the staff of Recep Tayyip Erdoğan University.SPSS program was used for statistical tests. Descriptive statistics, frequencies and distributions have been applied in the general distribution of the data. As statistical tests, normality test (Kolmogorov Simirnov and Saphiro Wilks) was performed.For data with normal distribution $\mathrm{p}<0.05$ significant group t-test was performed
\end{abstract}

\footnotetext{
*Sorumlu Yazar: Nihal AKOĞUZ YAZICI

e-mail: nihal.akoguz@erdogan.edu.tr Bu makale, 4. Uluslararası Avrasya Spor Eğitim ve Toplum Kongresi'nde (2019) sunulan özet bildiriden hazırlanmıştır
} 
for two independent groups in paired comparisons. In comparisons of three or more groups, Tukeys' HSD was made for the differences (post hoc) for which one-way Anova test (Oneway) was made.As a result; The level of motivation of the individual interested in sports to change his goals and objectives as his age progresses also affected this situation. Moreover, it can be said that the absorption scores of the participants are high in university, high school and university departments of higher education.

Keywords: University Personel, Motivation in Sports, Sports.

\section{Giriş}

Üniversiteler; üst düzeyde eğitim-öğretim sunarak intiyaç duyulan uluslararası niteliklere sahip insan gücü yetiştiren, çeşitli alanlarda eğitim, araştırma ve inovasyon yapabilen, kamu tüzel kişiliğine sahip; özerk, özgür, yetkin ve etkin yükseköğretim kurumlarıdır (Günay, 2004). Üniversiteler eğitim-öğretimden sorumlu akademik personel ve resmi işleri yürüten idari personellerden oluşmaktadır.

Personellerin çalışma alanlarının dışında da boş zamanlarını iyi ve etkin bir şekilde değerlendirmeleri iş verimliliğini artırmakta ve çalışma hayatını olumlu etkilemektedir (Yeniçeri vd. 2002). Kamu personelinin boş zaman değerlendirmesi ile ilgili yapılan bir çalışmada, boş zaman etkinliklerine katılmanın stres azaltıcı, dinlendirici, eğlendirici, sağlıklarına katkı sağlayıcı, eğitici, mutluluk verici gibi etkileri olduğu ortaya çıkmışıı (Özdağ vd. 2009). Yani bireyler, boş zamanlarını değerlendirmek, güçlenmek, kendini savunmak, sağlığını korumak gibi sebeplerin etkisiyle sportif faaliyetleri tercih etmişlerdir (Tel vd. 2000). Aynı zamanda spor yapmak kişilerin sosyal ve kişilik karakter gelişimi üzerinde de yararlı etkilere yol açtığı bilinmektedir (Yazıcı ve ark, 2019). Bu tercihlerde bir s orunu ele alış biçimi olan tutumlar oldukça önemlidir.

Bireylerin tutumlarını etkileyen birçok etkenden bahsedilebilir. Fakat güdülenme, bu tutumların yönünü, şiddetini, istikrarını belirleyen en etkin güçtür (Fid an, 1996). Güdülenme fiziksel ve psikolojik aktiviteleri başlatma, yönetme ve sürdürmeyi içeren her türlü süreç için kullanılan bir kavramdır (Gerrig \& Zimbardo, 2014). Ayrıca güdülenmenin tutumu güçlü kılan, yönlendiren, tutumun devamlılığı ile yönünü belirleyen içsel bir durum olduğu da söylenebilir (Hagger \& Chatzisarantis, 2007). İçsel olarak güdülenen birey, davranıştan aldığı hazdan; dışsal olarak güdülendiğinde ise dışardan kaynaklanan sonuçlar ve ya dışsal ödüllerden dolayı aktivitelere katılım sağlamaktadır (Ingledew, Markland \& Sheppard, 2004). Birey içsel olarak güdülendiği zaman dışsal ödül, baskı ve teşvik edici unsurlar için değil, keyif almak ya da kendine meydan okumak üzere harekete geçer (Ryan \& Deci, 2000b). Spora katıım sağlayan, spor yapmayı sürdürebilen ve sporu bir yaşam tarzı haline 
Akoğuz Yazıcı N., Maçça E. (2021). Üniversite Personelinin Sporda Güdülenme Düzeylerinin Araştırılması: Recep Tayyip Erdoğan Üniversitesi Örneği. Gaziantep Üniversitesi Spor Bilimleri Dergisi, 6(4), 329-342.

getiren kişilerin sayısını arttırmak için, katıımı tetikleyen etkenlerin belirlenmesi gerekmektedir (Edmunds, Ntoumanıs \& Duda, 2008). Güdülenme, birçok davranışın kavranmasında ve uygulanmaya geçilmesinde önemli bir etkiye sahiptir. Öğrenilen bir davranış uygulanmaya geçirilmediği zaman güdülenme kavramından bahsedilemeyeceği gibi, öğrenilen davranışın devamlılığını korumadığı zaman da güdülenmeden bahsetmek söz konusu olamaz (Erdem, 2008).

Güdülenme ve spor performansı birçok kez bir arada kullanılan benzer kavramlardır (Balcıoğlu, 2003). Spora katılımın elde edilmesi, devamlıı̆ı ve sporda istenilen ideal hedeflere ulaşılmasında güdülenme kavramının etkisinin bilinmesi ve güdülenmenin spora yönelik katkısının belirlenmesi gerekmektedir (Engür, 2002). Güdülenme ile ilgili yapılan spor ve egzersiz konularına ilişkin çalışmaları genel olarak iki amaç altında ele alabiliriz. Bu amaçlardan ilki, bazı insanların spor ve egzersiz yapmak için istekli olmaları ve spor yapmalarının; bazılarının da spor yapmaya hiç ilgi duymamaları ve spor yapmamalarının nedenlerini anlamaya yöneliktir. Yani ilk amaç katıım motivasyonu ile ilgili iken, İkinci amaç, başarı güdülenmesinin ne ifade ettiği, spor üzerindeki etkisi ve güdülenme stratejileri olarak belirtilmesi ile ilgilidir (Yeltepe, 2007).

Spora katıım güdülenmesine yönelik yapılan çalışmalar, beceri gelişimi ve kavranması, fiziksel olarak zindelik, arkadaşlık kurma ve başarmanın spora katıımı etkileyen en önemli unsur olduğunu ortaya koymaktadır. Spora katılım güdüleri kişileri aktif bir şeklide spor yapmaya teşvik eden güçlü bir etkenlerdir. Bu güdüler içsel ve dışsal özellikleriyle biçimlenmektedir. Güdülenen birey spora katılım için kendinin çok daha fazla hazır olduğunu görecektir (Gill vd.1983; Goluld vd. 1985).

Literatür incelendiğinde, spor yapan üniversite personellerinin sporda güdülenme düzeyleri araştırmak amacıyla yapılmış benzer bir çalışmanın olmadığı görüldü. Spor insan sağıı̆ı, yaratıcı düşünce, kurallara uyum sağlama ve kendini disipline etmesi açısından çalışan bireylerde oldukça önem arz etmektedir. Sporun insanı sosyalleştiren ve zararlı belli alışkanlıklardan uzak tutan yönü de tartışmasız bir gerçektir. Günümüzde modern yaşantının olumsuzluklarından etkilenmeden daha mutlu, daha sağlıklı ve iş hayatında daha etkin bir yaşam sürdürebilmek için spor çağdaş bir ihtiyaç durumuna gelmiştir. Spora yönelme kadar sporda süreklilik ve başarı hedeflerine ulaşılmasında da güdülenme etkilidir. Sporda katıımı, devamılı̆̆ı, performansı ve güdüsel süreci etkileyen pek çok içsel ve dışsal faktörler tespit etmek; 
bu faktörleri bireyin spora katıım isteğini arttıracak şekilde geliştirmek, hedeflerine ulaşmasında ve gerekli tedbirlerin alınmasında bireylerin başarı davranışlarını yönlendirmek ve bireyleri motive etmek oldukça önemlidir. Buradan hareketle bu çalışmada Recep Tayyip Erdoğan Üniversitesi personelinin sporda güdülenme düzeylerinin araştırılması ve ortaya konması amaç edinilmiştir.

\section{Yöntem}

\section{Araştırmanın Modeli}

Araştırma, betimsel tarama modelindedir. Betimsel istatistik, bir değişkene ilişkin sayısal değerlerin toplanması, betimlenmesi ve sunulmasına olanak sağlayan istatistiksel bir takım işlemdir (Büyüköztürk, 2010). Bu doğrultuda Recep Tayyip Erdoğan Üniversitesi personelinin sporda güdülenme düzeylerinin araştırılmaya çalışıldığı bu çalışma betimsel tarama modeline dayanmaktadır. Çalışmanın yapılabilmesi için RTE Üniversitesi Sosyal ve Beşeri Bilimler Etik Kurulu'ndan (2021/97 sayılı) "Etik Kurul Onayı" alınmıştır.

\section{Evren ve Örneklem}

Çalışmanın evrenini Recep Tayyip Erdoğan Üniversitesinde görev yapmakta olan yaklaşık 1891 personel oluştururken, örneklemini ise; Recep Tayyip Erdoğan Üniversitesi'nde çalışan, araştırmaya gönüllü olarak katılan 273 (97 kadın, 176 erkek) personel oluşturdu. Örneklem gurubunun Kadrolara göre dağııımı ise; 106 akademik ve 167 idari personel şeklindedir. Çalışma grubunu oluşturan katıımcıların demografik özelliklere göre dağııımı aşağıda tablo halinde verilmiştir.

Tablo 1. Tanımlayıcı Özellikler

\begin{tabular}{llll}
\hline Değişken & Grup & Frekans (n) & Yüzde (\%) \\
Yaş & 33 yaş ve altı & 94 & 34.4 \\
& $34-39$ yaş & 91 & 33.3 \\
Cinsiyet & 40 yaş ve üstü & 88 & 32.2 \\
& Kadın & 97 & 35.5 \\
Kadro Statüsü & Erkek & 176 & 64.5 \\
& Akademik Personel & 106 & 38,8 \\
Eğitim Düzeyi & İari Personel & 167 & 61,2 \\
& Lise & 24 & 8,8 \\
\multirow{5}{*}{ Spor Türü } & Üniversite & 134 & 49,1 \\
& Yüksek Lisans & 42 & 15,4 \\
Spor Yapma Yılı & Doktora & 73 & 26,7 \\
& Takım Sporları & 134 & 49,1 \\
& Bireysel Sporlar & 139 & 50,9 \\
& 4 yıl ve altı & 91 & 33,3 \\
& 5-13 yıl & 83 & 30,4 \\
& 14 yıl ve üstü & 99 & 36,3 \\
\hline
\end{tabular}


Katılımcılar cinsiyete göre dağılımları incelendiğinde, 176'sı $(\% 64,5)$ erkek, 97'si $(\% 35,5)$ kadın olarak tespit edilmiştir. Katılımcıların yaşa göre dağılımı, 94'u $(\% 34,4) 33$ yaş ve altı, 91'i $(\% 33,3) 34-39$ yaş arası ve 40 yaş ve üzeri ise 88'i $(\% 32,2)$ olarak tespit edilmiştir. Katılımcılar kadro statülerine göre 106’sı $(\% 61,2)$ akademik personel ve 167'si $(\% 38,8)$ idari personel olarak dağılmaktadır. Yaptıkları spor türüne göre; katılımcıların 134'ü $(\% 49,1)$ takım sporlarıyla, 139'u $(\% 50,9)$ ise bireysel sporlar ile ilgilendiği görülmektedir. Spor yapma yılına göre ise katılımcıların 91'i (\%33,3) 4 yı ve altı, 83'ü $(\% 30,4) 5-13$ yıl ve 99'u $(\% 36,3) 14$ yıl ve üstü olarak dağılım göstermektedir.

\section{Verilerin Toplanması}

İlk olarak araştırmanın amacına ilişkin mevcut bilgiler, literatürün taranmasıyla sistematik bir şekilde verilmiştir. Böylece konu hakkında teorik bir çerçeve oluşturulmuştur. Daha sonra Pelletier ve arkadaşları (2013) tarafından geliştirilen ve Öcal ve Sakallı (2018) tarafından Türkçeye uyarlanan Sporda Güdülenme Ölçeği II (SGÖ II) kullanılmıştır.

\section{Verilerin analizi}

Verilerin çözümlenmesi aşamasında SPSS 23 programı kullanılmıştır. Verilerin genel özelliklerini belirlemede tanımlayıcı istatistik, çapraz tablolama (Cross Tabulation) frekans ve yüzde dağılımlar yapılmıştır. İstatistik testler olarak personelin, Yaş, Cinsiyete, Kadro Statüsü, Eğitim Düzeyi, Yapılan Sporlar ve Spor Yapma Yılına bağlı olarak öncelikli olarak normallik testi (Kolmogorov Simirnov ve Saphiro Wilks) uygulandı. Verilerin normal dağılıma sahip olduğunun görülmesi üzerine $p<0,05$ anlamlılık düzeyinde ikili karşılaştırmalarda bağımsız iki grup için t-testi uygulandı. Üç ve üzeri grup karşılaştırmalarında ise tek yönlü Anova testi (Oneway) uygulandı Anlamlı bulunan farklılıklar için ikinci seviye test olarak (post hoc) Tukeys' HSD uygulandı.

\section{Bulgular}

$\mathrm{Bu}$ kısımda çalışmada yer alan üniversite personelinin sporda güdülenme düzeylerine ait sonuçlar tablolar ile sunulmuştur. Cinsiyet, Spor türüne ve Kadro statüsü durumuna bağlı olarak katılımcıların güdülenme düzeyleri arasında tüm alt boyutlarda önemli bir fark olup olmadığını belirlemek için $p<0,05$ anlamlılık düzeyinde t-testi uygulandı. Yaşa, Eğitim düzeyine ve Spor yapma yılına bağlı olarak katılımcıların güdülenme düzeyleri arasında tüm alt boyutlarda önemli bir fark olup 
olmadığını belirlemek için $p<0,05$ anlamlılık düzeyinde One Way Anova testi uygulandı.

Tablo 2.Katıımcıların cinsiyetleri bakımından sporda güdülenme alt boyut düzeyleri

\begin{tabular}{|c|c|c|c|c|c|c|c|}
\hline Değişken & Cinsiyet & $\mathbf{N}$ & Ortalama & Ss & df & $\mathbf{t}$ & $\mathbf{p}$ \\
\hline \multirow{2}{*}{ İçsel Güdülenme } & Kadın & 97 & 5,31 & 1,22 & \multirow{2}{*}{271} & \multirow{2}{*}{$-0,696$} & \multirow{2}{*}{0,487} \\
\hline & Erkek & 176 & 5,42 & 1,26 & & & \\
\hline \multirow{2}{*}{ Özümseme } & Kadın & 97 & 4,63 & 1,24 & \multirow{2}{*}{271} & \multirow{2}{*}{$-3,048$} & \multirow{2}{*}{$0,003^{*}$} \\
\hline & Erkek & 176 & 5,15 & 1,41 & & & \\
\hline \multirow{2}{*}{ Özdeşim } & Kadın & 97 & 5,25 & 1,27 & \multirow{2}{*}{271} & \multirow{2}{*}{$-0,935$} & \multirow{2}{*}{0,35} \\
\hline & Erkek & 176 & 5,41 & 1,30 & & & \\
\hline \multirow{2}{*}{ İçe Atım } & Kadın & 97 & 4,96 & 0,96 & \multirow{2}{*}{271} & \multirow{2}{*}{$-1,118$} & \multirow{2}{*}{0,265} \\
\hline & Erkek & 176 & 5,14 & 1,36 & & & \\
\hline \multirow{2}{*}{ Dışsal Düzenleme } & Kadın & 97 & 2,59 & 1,27 & \multirow{2}{*}{271} & \multirow{2}{*}{$-2,453$} & \multirow{2}{*}{$0,015^{*}$} \\
\hline & Erkek & 176 & 2,98 & 1,26 & & & \\
\hline \multirow{2}{*}{ Güdülenmeme } & Kadın & 97 & 3,00 & 1,33 & \multirow{2}{*}{271} & \multirow{2}{*}{0,496} & \multirow{2}{*}{0,621} \\
\hline & Erkek & 176 & 2,90 & 1,65 & & & \\
\hline
\end{tabular}

Test sonuçlarına göre, katılımcıların özümseme (t(271);-3,048; $p<0,05)$ ve dışsal düzenleme ( $t(271) ;-2,453 ; p<0,05)$ alt boyutlarında anlamlı farklılıklar ortaya çıkarken; içsel güdülenme, özdeşim, içe atım ve güdülenmeme alt boyutlarında anlamlı farklılıklar ortaya çıkmamıştır $(p>0,05)$.

Özümseme alt boyutunda erkek katıımcıların ortalamaları $(X=5,15 \pm 1,41)$, kadın katıımcıların ortalamalarından $(X=4,63 \pm 1,24)$ ve dışsal düzenleme alt boyutunda erkek katıımcıların ortalamaları $(X=2,98 \pm 1,26)$, kadın katılımcıların ortalamalarından $(X=2,59 \pm 1,27)$ anlamlı şekilde daha yüksektir.

Tablo 3.Katıımcıların yaşları bakımından sporda güdülenme alt boyut düzeyleri

\begin{tabular}{|c|c|c|c|c|c|c|c|c|}
\hline Değişken & Yaş & $\mathrm{N}$ & Ortalama & Ss & $\mathrm{sd}$ & $f$ & $p$ & Fark \\
\hline \multirow{3}{*}{ İçsel Güdülenme } & 33 yaş ve altı & 94 & 5,48 & 1,16 & \multirow{3}{*}{$2-271$} & \multirow{3}{*}{0,432} & \multirow{3}{*}{0,650} & \\
\hline & 34-39 yaş & 91 & 5,35 & 1,26 & & & & \\
\hline & 40 yaş ve üstü & 88 & 5,32 & 1,32 & & & & \\
\hline \multirow{3}{*}{ Özümseme } & 33 yaş ve altı & 94 & 4,77 & 1,28 & \multirow{3}{*}{$2-271$} & \multirow{3}{*}{2,313} & \multirow{3}{*}{0,101} & \\
\hline & 34-39 yaş & 91 & 5,20 & 1,32 & & & & \\
\hline & 40 yaş ve üstü & 88 & 4,93 & 1,49 & & & & \\
\hline \multirow{3}{*}{ Özdeşim } & 33 yaş ve altı & 94 & 5,39 & 1,12 & \multirow{3}{*}{$2-271$} & \multirow{3}{*}{2,114} & \multirow{3}{*}{0,123} & \\
\hline & 34-39 yaş & 91 & 5,53 & 1,20 & & & & \\
\hline & 40 yaş ve üstü & 88 & 5,14 & 1,52 & & & & \\
\hline \multirow{2}{*}{ İçe Atım } & 33 yaş ve altı & 94 & 4,96 & 1,05 & \multirow{2}{*}{$2-271$} & \multirow{2}{*}{3,456} & \multirow{2}{*}{$0,033^{*}$} & \multirow{2}{*}{$3<2$} \\
\hline & 34-39 yaş & 91 & 5,35 & 1,19 & & & & \\
\hline
\end{tabular}


Akoğuz Yazıcı N., Maçça E. (2021). Üniversite Personelinin Sporda Güdülenme Düzeylerinin Araştırılması: Recep Tayyip Erdoğan Üniversitesi Örneği. Gaziantep Üniversitesi Spor Bilimleri Dergisi, 6(4), 329-342.

\begin{tabular}{lccccccccc} 
& 40 yaş ve üstü & 88 & 4,91 & 1,41 & & & & \\
& 33 yaş ve altı & 94 & 2,75 & 1,25 & & & & \\
Dışsal Düzenleme & $34-39$ yaş & 91 & 2,63 & 1,09 & $2-271$ & 4,103 & $\mathbf{0 , 0 1 8}^{*}$ & $2<3$ \\
& 40 yaş ve üstü & 88 & 3,15 & 1,44 & & & & \\
Güdülenmeme & 33 yaş ve altı & 94 & 2,83 & 1,39 & & & & \\
& $34-39$ yaş & 91 & 2,69 & 1,45 & $2-271$ & 3,813 & $\mathbf{0 , 0 2 3 ^ { * }}$ & $2<3$ \\
& 40 yaş ve üstü & 88 & 3,30 & 1,74 & & & & \\
\hline
\end{tabular}

1) 33 yaş ve altı, 2) 34-39 yaş ve 3) 40 yaş ve üstü

Test sonuçlarına göre; katıımcıların içe atım (f2,271; 3,$456 ; p<0,05)$, dışsal

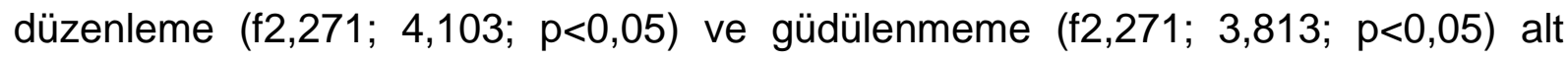
boyutlarında anlamlı farklııklar ortaya çıkarken; içsel güdülenme, özümseme ve özdeşim alt boyutlarında anlamlı farklılıklar ortaya çıkmamışıı $(p>0,05)$.

Tablo 4: Katılımcıların kadro statüsü bakımından sporda güdülenme alt boyut düzeyleri

\begin{tabular}{|c|c|c|c|c|c|c|c|}
\hline Değişken & Kadro Statüsü & $\mathrm{N}$ & Ortalama & Ss & df & $\mathrm{t}$ & $\mathrm{p}$ \\
\hline \multirow[t]{2}{*}{ İçsel Güdülenme } & Akademik Personel & 106 & 5,50 & 1,25 & \multirow{2}{*}{271} & \multirow{2}{*}{1,268} & \multirow{2}{*}{0,206} \\
\hline & İdari Personel & 167 & 5,31 & 1,24 & & & \\
\hline \multirow[t]{2}{*}{ Özümseme } & Akademik Personel & 106 & 5,22 & 1,29 & \multirow{2}{*}{271} & \multirow{2}{*}{2,444} & \multirow{2}{*}{$0,015^{*}$} \\
\hline & İdari Personel & 167 & 4,80 & 1,40 & & & \\
\hline \multirow[t]{2}{*}{ Özdeşim } & Akademik Personel & 106 & 5,57 & 1,21 & \multirow{2}{*}{271} & \multirow{2}{*}{2,219} & \multirow{2}{*}{$0,027^{*}$} \\
\hline & İdari Personel & 167 & 5,22 & 1,33 & & & \\
\hline \multirow[t]{2}{*}{ İçe Atım } & Akademik Personel & 106 & 5,27 & 1,16 & \multirow{2}{*}{271} & \multirow{2}{*}{2,106} & \multirow{2}{*}{$0,036^{*}$} \\
\hline & İdari Personel & 167 & 4,95 & 1,26 & & & \\
\hline \multirow[t]{2}{*}{ Dışsal Düzenleme } & Akademik Personel & 106 & 2,78 & 1,30 & \multirow{2}{*}{271} & \multirow{2}{*}{$-0,598$} & \multirow{2}{*}{0,55} \\
\hline & İdari Personel & 167 & 2,88 & 1,27 & & & \\
\hline \multirow[t]{2}{*}{ Güdülenmeme } & Akademik Personel & 106 & 2,74 & 1,58 & \multirow{2}{*}{271} & \multirow{2}{*}{$-1,695$} & \multirow{2}{*}{0,091} \\
\hline & İdari Personel & 167 & 3,06 & 1,52 & & & \\
\hline
\end{tabular}

Test sonuçlarına göre, katılımcıların özümseme (t(271);-2,444; $p<0,05)$, özdeşim ( $t(271) ; 2,219 ; p<0,05)$ ve içe atım $(t(271) ; 2,106 ; p<0,05)$ alt boyutlarında anlamlı farklııklar ortaya çıkarken; içsel güdülenme, dışsal düzenleme ve güdülenmeme alt boyutlarında anlamlı farklııılar ortaya çıkmamıştır $(p>0,05)$. 
Akoğuz Yazıcı N., Maçça E. (2021). Üniversite Personelinin Sporda Güdülenme Düzeylerinin Araştırılması: Recep Tayyip Erdoğan Üniversitesi Örneği. Gaziantep Üniversitesi Spor Bilimleri Dergisi, 6(4), 329-342.

Tablo 5: Katılımcıların eğitim düzeyi bakımından sporda güdülenme alt boyut düzeyleri

\begin{tabular}{|c|c|c|c|c|c|c|c|c|}
\hline Değişken & Eğitim Düzeyi & $\mathrm{N}$ & Ortalama & Ss & df & $f$ & $p$ & Fark \\
\hline & Lise & 24 & 5,22 & 1,45 & & \multirow{4}{*}{0,87} & & \\
\hline \multirow{3}{*}{ İçsel Güdülenme } & Üniversite & 134 & 5,30 & 1,22 & \multirow{3}{*}{ 3-269 } & & \multirow{3}{*}{0,457} & \multirow{23}{*}{$2<4$} \\
\hline & Yüksek Lisans & 42 & 5,45 & 1,29 & & & & \\
\hline & Doktora & 73 & 5,56 & 1,20 & & & & \\
\hline \multirow{4}{*}{ Özümseme } & Lise & 24 & 4,92 & 1,44 & \multirow{4}{*}{$3-269$} & \multirow{4}{*}{3,625} & \multirow{4}{*}{$0,014^{*}$} & \\
\hline & Üniversite & 134 & 4,72 & 1,44 & & & & \\
\hline & Yüksek Lisans & 42 & 5,10 & 1,33 & & & & \\
\hline & Doktora & 73 & 5,35 & 1,15 & & & & \\
\hline \multirow{4}{*}{ Özdeşim } & Lise & 24 & 5,22 & 1,64 & \multirow{4}{*}{ 3-269 } & \multirow{4}{*}{2,155} & \multirow{4}{*}{0,094} & \\
\hline & Üniversite & 134 & 5,18 & 1,30 & & & & \\
\hline & Yüksek Lisans & 42 & 5,48 & 1,37 & & & & \\
\hline & Doktora & 73 & 5,63 & 1,05 & & & & \\
\hline \multirow{4}{*}{ İçe Atım } & Lise & 24 & 5,01 & 1,57 & \multirow{4}{*}{ 3-269 } & \multirow{4}{*}{2,546} & \multirow{4}{*}{0,056} & \\
\hline & Üniversite & 134 & 4,90 & 1,25 & & & & \\
\hline & Yüksek Lisans & 42 & 5,12 & 1,10 & & & & \\
\hline & Doktora & 73 & 5,39 & 1,10 & & & & \\
\hline \multirow{4}{*}{ Dışsal Düzenleme } & Lise & 24 & 3,07 & 1,54 & \multirow{4}{*}{ 3-269 } & \multirow{4}{*}{0,541} & \multirow{4}{*}{0,655} & \\
\hline & Üniversite & 134 & 2,85 & 1,19 & & & & \\
\hline & Yüksek Lisans & 42 & 2,66 & 1,36 & & & & \\
\hline & Doktora & 73 & 2,85 & 1,31 & & & & \\
\hline \multirow{4}{*}{ Güdülenmeme } & Lise & 24 & 3,51 & 1,88 & \multirow{4}{*}{ 3-269 } & \multirow{4}{*}{2,221} & \multirow{4}{*}{0,086} & \\
\hline & Üniversite & 134 & 2,98 & 1,48 & & & & \\
\hline & Yüksek Lisans & 42 & 3,00 & 1,44 & & & & \\
\hline & Doktora & 73 & 2,62 & 1,57 & & & & \\
\hline
\end{tabular}

1) Lise, 2) Üniversite, 3) Yüksek Lisans ve 4) Doktora

Tablo 6: Katılımcıların spor türü bakımından sporda güdülenme alt boyut düzeyleri

\begin{tabular}{|c|c|c|c|c|c|c|c|}
\hline Değişken & Spor Türü & $\mathrm{N}$ & Ortalama & Ss & df & $\mathrm{t}$ & $p$ \\
\hline \multirow[t]{2}{*}{ İçsel Güdülenme } & Takım Sporları & 134 & 5,60 & 1,16 & 271 & 2.922 & $.004^{*}$ \\
\hline & Bireysel Sporlar & 139 & 5,17 & 1,29 & & & \\
\hline \multirow[t]{2}{*}{ Özümseme } & Takım Sporları & 134 & 5,30 & 1,28 & 271 & 4.124 & $.000^{*}$ \\
\hline & Bireysel Sporlar & 139 & 4,64 & 1,38 & & & \\
\hline \multirow[t]{2}{*}{ Özdeşim } & Takım Sporları & 134 & 5,50 & 1,22 & 271 & 1.887 & .060 \\
\hline & Bireysel Sporlar & 139 & 5,21 & 1,35 & & & \\
\hline \multirow[t]{2}{*}{ İçe Atım } & Takım Sporları & 134 & 5,26 & 1,34 & 271 & 2.514 & $.013^{*}$ \\
\hline & Bireysel Sporlar & 139 & 4,89 & 1,09 & & & \\
\hline \multirow{2}{*}{ Dışsal Düzenleme } & Takım Sporları & 134 & 3,09 & 1,18 & 271 & 3.233 & $.001^{*}$ \\
\hline & Bireysel Sporlar & 139 & 2,60 & 1,33 & & & \\
\hline \multirow[t]{2}{*}{ Güdülenmeme } & Takım Sporları & 134 & 2,81 & 1,67 & 271 & -1.294 & .197 \\
\hline & Bireysel Sporlar & 139 & 3,05 & 1,41 & & & \\
\hline
\end{tabular}

Test sonuçlarına göre, katııımcıların içsel güdülenme (t(271); 2,922; $p<0,05)$, özümseme (t(271); 4,124; $p<0,05)$, dışsal düzenleme $(t(271) ; 3,233 ; p<0,05)$ içe atım $(\mathrm{t}(271) ; 2,514 ; p<0,05)$ alt boyutunda anlamlı farklııklar ortaya çıkarken; özdeşim ve güdülenmeme alt boyutlarında anlamlı farklıııklar ortaya çıkmamıştır $(p>0,05)$. 
Tablo 7: Katılımcıların spor yapma yılı bakımından sporda güdülenme alt boyut düzeyleri

\begin{tabular}{|c|c|c|c|c|c|c|c|c|}
\hline Değişken & $\begin{array}{c}\text { Spor Yapma } \\
\text { Yılı }\end{array}$ & $\mathrm{N}$ & Ortalama & Ss & df & $f$ & $p$ & Fark \\
\hline \multirow{3}{*}{ İçsel Güdülenme } & 4 yıl ve altı & 91 & 5,11 & 1,15 & \multirow{3}{*}{$2-270$} & \multirow{3}{*}{6,393} & \multirow{3}{*}{$0,002^{*}$} & \multirow{3}{*}{$\begin{array}{l}1<3 \\
2<3\end{array}$} \\
\hline & 5-13 yıl & 83 & 5,29 & 1,27 & & & & \\
\hline & 14 yıl ve üstü & 99 & 5,72 & 1,25 & & & & \\
\hline \multirow{3}{*}{ Özümseme } & 4 yıl ve altı & 91 & 4,53 & 1,23 & \multirow{3}{*}{$2-270$} & \multirow{3}{*}{12,67} & \multirow{3}{*}{0,000 * } & \multirow{3}{*}{$\begin{array}{l}1<3 \\
2<3\end{array}$} \\
\hline & 5-13 yıl & 83 & 4,84 & 1,32 & & & & \\
\hline & 14 yıl ve üstü & 99 & 5,47 & 1,39 & & & & \\
\hline \multirow{3}{*}{ Özdeşim } & 4 yıl ve altı & 91 & 4,93 & 1,18 & \multirow{3}{*}{$2-270$} & \multirow{3}{*}{8,026} & \multirow{3}{*}{0,000 * } & \multirow{3}{*}{$\begin{array}{l}1<2 \\
1<3\end{array}$} \\
\hline & $5-13$ yıl & 83 & 5,48 & 1,30 & & & & \\
\hline & 14 yıl ve üstü & 99 & 5,64 & 1,29 & & & & \\
\hline \multirow{3}{*}{ İçe Atım } & 4 yıl ve altı & 91 & 4,70 & 1,05 & \multirow{3}{*}{$2-270$} & \multirow{3}{*}{8,841} & \multirow{3}{*}{0,000 * } & \multirow{3}{*}{$1<3$} \\
\hline & $5-13$ yıl & 83 & 5,05 & 1,18 & & & & \\
\hline & 14 yıl ve üstü & 99 & 5,43 & 1,34 & & & & \\
\hline \multirow{3}{*}{ Dışsal Düzenleme } & 4 yıl ve altı & 91 & 2,77 & 1,29 & \multirow{3}{*}{$2-270$} & \multirow{3}{*}{2,088} & \multirow{3}{*}{0,126} & \multirow{6}{*}{$\begin{array}{l}3<1 \\
3<2\end{array}$} \\
\hline & 5-13 yıl & 83 & 2,67 & 1,42 & & & & \\
\hline & 14 yıl ve üstü & 99 & 3,04 & 1,12 & & & & \\
\hline \multirow{3}{*}{ Güdülenmeme } & 4 yıl ve altı & 91 & 3,07 & 1,39 & \multirow{3}{*}{$2-270$} & \multirow{3}{*}{10,246} & \multirow{3}{*}{0,000 * } & \\
\hline & 5-13 yıl & 83 & 3,40 & 1,55 & & & & \\
\hline & 14 yıl ve üstü & 99 & 2,42 & 1,54 & & & & \\
\hline
\end{tabular}

1)4 yıl ve altı, 2) 5-13 yıl ve 3) 14 yıl ve üstü

Test sonuçlarına göre; katılımcıların özümseme (f2,271; 12,67; $P<0,05)$, içe atım (f2,271; 8,841; $p<0,05)$, güdülenmeme (f2,271; 10,246; $p<0,05)$, içsel güdülenme $(f 2,271 ; 6,393 ; P<0,05)$ ve özdeşim $(f 2,271 ; 8,026 ; p<0,05)$ alt boyutlarında anlamlı farklılıklar ortaya çıkarken; dışsal düzenleme alt boyutunda anlamlı farklılıklar ortaya çıkmamıştır ( $p>0,05)$.

\section{Tartışma ve Sonuç}

$\mathrm{Bu}$ bölümde literatür taraması göz önünde bulundurularak elde edilen veriler tartışılmıştır. Cinsiyete bağlı olarak İçsel güdülenme, özdeşim, içe atım ve güdülenmeme alt boyutlarına göre istatistiksel açıdan anlamlı olarak farklılaşmanın olmadığı görüldü. Dahası, erkeklerin özümseme ve dışsal düzenleme puanlarının kadın katılımcılardan anlamlı şekilde daha yüksek olduğu görüldü.

Literatür incelendiğinde erkek katılımcıların kadın katılımcılara göre; benlik algısı daha gelişmiş olduğu, fiziksel aktivitenin öneminin bu bilincin farkındalığıyla birlikte daha da önem kazandığı ve kaygı-utanç gibi içsel baskılarla daha çok desteklendiği söylenebilir. Cinsiyet ve güdülenme üzerine benzer bir çalışma olan 
Kazak (2004)' ın dört takım (futbol, voleybol, hentbol, basketbol) ve beş bireysel (atletim, taekwondo, judo, tenis, güreş) spor dalı olmak üzere toplam 9 spor branşındaki farklı gruplarla yapılan çalışmalar sonucunda; cinsiyetler arasında, sadece dışsal düzenleme ve içsel güdülenme boyutlarında fark bulunmuştur. Gill ve ark. (1983), Ryan ve ark. (1997)'nın yapmış oldukları farklı bir çalışmada kadın katılımcıların, erkek katılımcılara göre daha az dışsal olarak güdülendiklerini tespit etmişlerdir.

Yaşa bağlı olarak içsel güdülenme, özümseme ve özdeşim alt boyutlarında anlamlı farklılık olmadığı görülürken; personelin yaş faktörüne göre içe atım, dışsal düzenleme ve güdülenmeme alt boyutlarında anlamlı farklılıklar belirlendi. Buna bağlı olarak spor ile ilgilenen personelin yaşı ilerledikçe amaçları ve hedefleri değişmekte olduğundan güdülenme düzeylerini etkilediği ön görülebilir. 34-39 yaş aralığındaki katılımcıların diğer yaş grubundaki katılımcılara göre; tehdit ya da ödül ile desteklenen bir güdülenmeyle spor yaptıklarını, spora ayırdıkları vakitle kendilerini daha iyi ve değerli hissettikleri söylenebilir. 40 yaş-üstü katılımcıların diğer yaş grubundaki katılımcılara göre; davranışlarının dışsal kaynaklar tarafından kontrol edildiği ve spora katılım nedenlerinin daha çok başkalarının baskıları, ödül ve saygı görme istekleri olabilir.

Literatürde bu sonucu destekler çalışma bulunmakla birlikte, farklılık gösteren çalışmalar da bulunmaktadır. Kavalcı ve Kalkavan (2018)' ın güreşçiler örnekleminde yapmış olduğu araştırmada; yaş değişkenine göre sporcuların dışsal güdülenme, içsel güdülenme ve güdülenmeme alt boyutların düzeylerine bakıldığında 26 yaş ve üstü sporcuların daha yüksek puan aldıkları görülmektedir. Akman, K. (2017)'ın öğrenciler örnekleminde yapmış olduğu araştırmada 15 yaş altı, 16-17 ve 18 yaş ve üzeri üç ayrı yaş grubu oluşturulmuş içsel güdülenme düzeyinde en yüksek puanı 18 yaş ve üzeri aldığını belirtmiştir. Kazak (2004)'ın dört takım (futbol, voleybol, hentbol, basketbol) ve beş bireysel (atletim, taekwondo, judo, tenis, güreş) spor dalı olmak üzere toplam 9 spor branşındaki farklı gruplarla yapılan çalışmalar sonucunda; sporcu öğrencilerin yaşı ilerledikçe içsel güdülenme puanlarının azaldığını ortaya koymuştur.

Kadro statüsüne bağlı olarak içsel güdülenme, dışsal düzenleme ve güdülenmeme alt boyutlarında farklılaşmanın olmadığı; akademik personelin özümseme, özdeşim ve içe atım puanları idari personelin puanlarından anlamlı şekilde daha yüksek olduğu görüldü. Akademik personelin idari personele göre; kimliklerinin bir yansıması olarak gördükleri fiziksel aktiviteyle birlikte yeni şeyler öğrenerek, önem 
Akoğuz Yazıcı N., Maçça E. (2021). Üniversite Personelinin Sporda Güdülenme Düzeylerinin Araştırılması: Recep Tayyip Erdoğan Üniversitesi Örneği. Gaziantep Üniversitesi Spor Bilimleri Dergisi, 6(4), 329-342.

verdikleri özelliklerini geliştirerek öz değerlerine katkı sağladıkları söylenebilir. Literatür incelendiğinde kadro statüsüne göre güdülenme düzeyini inceleyen çalışmalara rastlanılmamıştır. Bu durum araştırma sonuçlarını kıyaslama noktasında mevcut araştırmanın bir sınırlılığı olarak görülebilir.

Eğitim düzeyine bağlı olarak içe atım, dışsal düzenleme, güdülenmeme, içsel güdülenme ve özdeşim alt boyutlarında anlamlı farklılıklar belirlendi. Eğitim düzeyi farklılığının, bireylerin bütün yaşamlarında kendini gösterdiği gibi spor alanında da yansımalarının olduğu, eğitim düzeyi arttıkça, insanların bedenlerine daha fazla ilgi gösterdiği ifade edilebilir. Ayrıca, eğitim düzeyinin artmasına paralel olarak insanların spordan beklentileri ve spor yapma amaçlarının da değişikliğe uğradığı söylenebilir. Literatür incelendiğinde; Şirin ve ark. (2008)'nın öğrenciler örnekleminde yapmış olduğu araştırmada öğrencilerinin spora katılımında en önemli nedenler olarak takım üyeliği/ruhu, beceri gelişimi ve hareket/aktif olma olarak belirlendiği görülmüştür. Bireylerin eğitim düzeyi yükseldikçe, spora katılım hususunda bilgi ve bilinç düzeylerinin arttığı daha fazla spor yaptıkları birçok araştırma ile desteklenmektedir.

Spor türüne bağlı olarak özdeşim, içe atım ve güdülenmeme alt boyutlarında anlamlı farklılıklar görülmedi. Literatür incelendiğinde; Akbulut, K.M. ve ark (2015)'un öğrenciler örnekleminde yapmış olduğu araştırmada, bireysel spor yapan öğrencilerle takım sporu yapan katıımcılar karşılaştırıldığında bireysel spor yapan öğrencilerin sezinleme zamanlarının daha iyi çıkması nedeniyle yapılan çalışmayla paralellik göstermediği görülmektedir.

Spor yapma yılına bağlı olarak dışsal düzenleme alt boyutlarında anlamlı farklılık olmadığı görülürken; personelin spor yapma faktörüne göre içsel güdülenme, özümseme, özdeşim, içe atım ve güdülenmeme alt boyutlarında anlamlı farklılıklar belirlendi. Elde ettiğimiz bulgular ışığında, sporcuların süreç içerisinde yeni teknik özellikler kazanması ve kendilerini daha iyi seviyede hissetmeleri aynı zamanda başkaları tarafından takdir edilme duygusundan kaynaklandığı söylenebilir.

Literatürde bu sonucunu destekler çalışma bulunmakla birlikte, farklılık gösteren çalışmalar da bulunmaktadır. Akbulut, K.M. ve ark (2015)'un öğrenciler örnekleminde yapmış olduğu araştırmada, sezinleme zamanı, spor yılı ve antrenman yaşı arttıkça iyileştiği; yaşla birlikte sezinleme zamanı performansı artmakta, yapılan deneyimle birlikte paralel olarak azalmakta olduğu görülmüştür. Esentürk, O.K. (2014)'ün örneklemini öğrencilerin oluşturduğu çalışmada; spor yapma yılı uzun süre spor yapan öğrencilerin, kısa süre yapanlara kıyasla dışsal beklentilere daha fazla sahip oldukları 
tespit edilmiştir. Akman, K. (2017)'ın öğrenciler örnekleminde yaptığı çalışmada spor yapma yılı arttıkça dışsal güdülenme düzeyinin de yükseldiği tespit edilmiştir.

Sonuç olarak; yaş değişkenine göre içe atım, dışsal düzenleme ve güdülenmeme alt boyutları, cinsiyet değişkenine göre özümseme ve dışsal düzenleme alt boyutları, kadro statüsü değişkenine göre özümseme, özdeşim ve içe atım alt boyutları, eğitim düzeyi değişkenine göre özümseme ve içe atım alt boyutları, spor türü değişkenine göre içsel güdülenme, özümseme, içe atım ve dışsal düzenleme alt boyutları, spor yapma yılı değişkenine göre dışsal düzenleme alt boyutu harici diğer tüm alt boyutlarda katılımcıların sporda güdülenme düzeylerinin anlamlı bir şekilde farklılaştığını gösterdi.

\section{Kaynaklar}

Akbulut, M.K., Aktağ, I., Akpınar, S. (2015). Takım sporu ile bireysel spor yapan öğrencilerin sezinleme zamanlarının incelenmesi, Spor Bilimleri Dergisi Hacettepe Journal of Sport Sciences 2015, 26 (4), 154-164

Akman, K (2017). Oryantiring sporu yapan lise öğrencilerinin sporda güdülenme düzeylerinin farklı değişkenler açısından incelenmesi, Yüksek Lisans Tezi, Beden Eğitimi ve Spor Öğretmenliği Bilim Dalı, Atatürk Üniversitesi, Mayıs, Erzurum.

Balcıoğlu, İ. (2003). Sporun sosyolojisi ve psikolojisi. İstanbul: Bilge yayıncılık.

Büyüköztürk, Ş.(2010). Sosyal bilimler için veri analizi el kitabı. Ankara: Pegem Akademi Yayınları.

Engür, M. (2002). Elitsporcularda başarı motivasyonun, durumluk kaygı düzeyleri üzerine etkisi (Yayımlanmamış doktora tezi). Ege Üniversitesi, Sağlık Bilimleri Enstitüsü, İzmir.

Erdem, M. (2008). Amerikan futbolu sporcularında sporda güdülenme ölçeğinin geliştirilmesi, Yüksek Lisans Tezi, Ankara Üniversitesi Sağlık Bilimleri Enstitüsü Beden Eğitimi ve Spor Anabilim Dalı, Ankara.

Esentürk O.K (2014). Lise düzeyinde öğrenim gören ve okullar arası spor müsabakalarına katılan sporcu öğrencilerin güdülenme ve saldırganlık düzeylerinin incelenmesi, Yüksek Lisans Tezi, Gazi Üniversitesi, Eğitim Bilimleri Enstitüsü, Beden Eğitimi ve Spor Öğretmenliği Anabilim Dalı, Mart, Ankara. 
Edmunds, J., Ntoumanis, N. \& Duda, J. L. (2008). Testing a self-determination theorybased teaching style intervention in the exercise domain. European Journal of Social Psychology, 38(2), 375-388

Gerrig, R.J., \& Zimbardo, P.G. (2014). Psikoloji ve yaşam: psikolojiye giriş. (G. Sart Çev.). Ankara: Nobel.

Gill, D. L., Gross, J. B., \& Huddleston, S., Participation motivation in young sports, International Journal of Sport Psychology, 14,1, 1-14, 1983.

Günay, D. (2004). Üniversitenin Niteliği, akademik özgürlük ve üniversite özerkliği". I.Uluslararası Üniversite Eğitimi Kongresi, İstanbul: Fatih Üniversitesi.

Hagger, M. S., \& Chatzisarantis N. L. D. (2007). Intrinsic motivation and self determination in exercise and sport. Human Kinetics.

Ingledew, D.K., Markland, D., \& Sheppard, K.E. (2004). Personality and selfdetermination of exercise behaviour. Personality and Individual Differences, 36(8), 1921-1932

Kavalcı, İ., Kalkavan, A. (2018). Türkiye şampiyonasına katılan grekoromen güreşçilerin sporda güdülenme durumlarının araştırılması, 3. Uluslararası Avrasya Spor Eğitim ve Toplum Kongresi.

Kazak, Z. (2004), Sporda güdülenme ölçeği-SGÖ-nin türk sporcuları için güvenirlilik ve geçerlilik çalışması" Hacettepe üniversitesi Spor bilimleri dergisi 2004, 15 (4), 191-206.

Öcal, K, Sakallı D. (2018). Sporda güdülenme ölçeği-II'nin Türkçe uyarlaması: Geçerlik ve güvenirlik çalışması, International Journal of Sports Exercıse \& Traning Sciences 2018, Vol.4, Issue 1, 39-48

Ryan, R.M., \& Deci, E.L. (2000b). Intrinsic and extrinsic motivations: Classic definitions and new directions. Contemporary Educational Psychology, 25(1),

Ryan RM. Frederick CM. Lepes D. Rubio N. Sheldon KM. (1997). İntrinsic motivation end exercise adherence. International Journal of Sport Psychology, 1997, 28: 14.54-67

Saygılı, G., Atay, E., Erarslan, M., Hekim M. (2015). Düzenli olarak spor yapan ve yapmayan öğrencilerin kişilik özellikleri ile akademik başarıları arasındaki ilişkinin incelenmesi, Ocak 2015 Cilt:23 No:1 Kastamonu Eğitim Dergisi 161170 
Şirin, F. E., Çağlayan, S.H., Çetin, Ç.M. ve İnce, A. (2008). Spor yapan lise öğrencilerinin spora katıım motivasyonlarına etki eden faktörlerin belirlenmesi, Niğde Üniversitesi Beden Eğitimi ve Spor Bilimleri Dergisi, 2(2), 98-110.

Tel, M., Öcalan, M., Yaman, M. (2000). Taekwondocuların bu sporu tercih etme nedenleri ve sosyo-ekonomik durumları. Türkiye Sosyal Araştırmalar Dergisi, Cilt:3, Sayı:3.

Özdağ, S., Yeniçeri, M., Fişekçioğlu, İ.B., Akçakoyun F., Kürkçü, R.,(2009). Devlet memurlarının boş zaman değerlendirme eğilimleri, Antropometrik ve Fiziksel Uygunluk Seviyeleri. Selçuk Üniversitesi Sosyal Bilimler Enstitüsü Dergisi, 22, 307-323.

Yazıcı, A.G., Ogan, M., Öztürk, M. E. \& Özdemir, K. (2019). Student attitudes towards basketball. Journal of Physical Education Research, 6(1), 42-48.

Yeltepe, H. (2007). Spor ve Egzersiz Psikolojisi. Epsilon Yayıncılık.

Yeniçeri, M., Coşkun, B. ve Özkan, H. (2002). Muğla merkezindeki memurların boş zaman değerlendirme eğilimlerinin belirlenmesi üzerine bir araştırma. Muğla Üniversitesi SBE Dergisi, 7, 1-20. 